\title{
The Death Penalty and Human Dignity: An Existential Fallacy
}

\author{
Susan Nagelsen ${ }^{1, *}$ and Charles Huckelbury ${ }^{2}$ \\ 1 Writing Department, Curry College, Milton, MA 02186, USA \\ 2 Independent scholar, Henniker, NH 03242, USA; huckelbury@gmail.com \\ * Correspondence: snagelse0914@curry.edu; Tel.: +1-603-496-6804 \\ Academic Editor: Robert Johnson \\ Received: 28 February 2016; Accepted: 30 May 2016; Published: 2 June 2016
}

\begin{abstract}
Proponents of capital punishment in the United States frequently cite the evolution from electrocution and hanging to lethal injection as an indication that the evolving standards of decency exhibited by such a transition demonstrate a respect for human dignity. This essay examines that claim by evaluating two standards for assessing whether an act comports with accepted definitions of human dignity: a personal-achievement model, based on work by economist Amartya Sen of Harvard University, and a universal and intrinsic approach to human dignity articulated by criminologist Robert Johnson of the American University. We evaluate Sen's capabilities model through the lens of a condemned prisoner's ability to achieve self-defined goals. We then assess Johnson's claim that preserving human dignity requires an elimination of the death penalty, irrespective of any prisoner's ability to lead a restricted, albeit goal-directed, existence.
\end{abstract}

Keywords: human dignity; death penalty; capabilities approach; lethal injection

Human dignity is a somewhat protean term, assuming different configurations and meanings as one travels the globe, or even between geographical sections of a single country, including the United States. As Leslie Meltzer Henry observes in a law review article, "[C]ontrasting views about dignity's definition, usefulness, and ultimate purpose have emerged" ([1], p. 172). Common factors do, however, exist in every description-and in the social and political attempts to circumvent accepted definitions.

In the United States, for example, proponents of capital punishment extol the shift away from firing squads, hanging, gassing, and electrocution as means of executing condemned men and women. The Federal government and most states have now adopted lethal injection as a more "humane" method of killing, with a bizarre emphasis on maintaining the condemned prisoner's human dignity. Professor Henry quotes legal theorist Ronal Dworkin's claim that "the principals of human dignity...are embodied in the Constitution and are now common ground in America" ([1], p. 172). We would point out that the same Constitution referenced by Dworkin explicitly permits the government to kill its citizens so long as they were provided a fair and impartial trial, allowed representation by counsel, and the proceedings followed due process of law.

Using Timothy McVeigh's execution as one example of the humanitarian argument for capital punishment, witnesses described a "very orchestrated, clinical procedure" [2], although a family member of one of McVeigh's victims complained that the process was just like going to sleep, clearly ignoring the intent of the government to kill McVeigh and not torture him. Even a cursory glance, however, at any authoritative definition reveals both the logical inconsistency of such a "humanitarian" proposition and its underlying hypocrisy.

Duhaime's Law Dictionary concisely defines human dignity as "An individual or group's sense of self-respect and self-worth, physical and psychological integrity and empowerment" [3]. How, then, does sentencing men and women to death and confining them for decades in a small cell before 
execution with the knowledge that his or her life could end with the stroke of a pen preserve that person's self-worth, self-respect, and physical and psychological integrity? Moreover, the only persons empowered by executions are the government and its representatives, hardly the result anticipated by accepted definitions. One refutation of such a practice is the number of condemned prisoners who waive their appeals and embrace their executions, rather than spend decades in a cell anxiously waiting for the government to decide when they die [4].

Robert Johnson is a professor of justice, law, and criminology at American University, a Distinguished Alumnus of the Nelson A. Rockefeller College of Public Affairs and Policy, and a recognized expert on issues involving criminal justice and social policy. In a paper dealing specifically with the mutually exclusive concepts of human dignity and capital punishment, he argues that a death sentence dehumanizes the condemned and severely constrains his or her options, reducing "the capacity [to] make choices that shape the course of one's life...choices of self-determination" ([5], p. 585). Johnson further states, "The essential respect due another human being is to treat him or her as a human being with the right to live as a human being" ([5], p. 586). Executing someone is therefore incompatible with preserving his or her human dignity, since, by any definition, taking someone's life eliminates any control over one's environment and deprives the victim of that capacity for making choices regarding self-determination.

Here it is appropriate to revisit the Nobel Laureate, economist, and philosopher Amartya Sen's capabilities approach to human dignity in order to address the issue raised by Johnson. Sen is unequivocal. Addressing the issues of worldwide poverty and economic and social sustainability, he recognizes that

[I]ndividual agency is, ultimately, central to addressing these deprivations...the freedom of agency that we individually have is inescapably qualified and constrained by the social, political and economic opportunities that are available to us. There is a deep complementarity between the individual agency and social arrangements ([6], p. xi).

Sen's capabilities approach is thus built on two normative assertions, both ensconced firmly in a framework erected on an individual's interpretation: that the freedom to achieve well-being is of primary moral importance and that the freedom to achieve that goal is grounded in the individual's capabilities [7]. This approach is instructive only if, as Martha Nussbaum has elaborated, an individual is supplied with specific human functional capabilities.

Nussbaum is the Ernst Freund Distinguished Service Professor of Law and Ethics at the University of Chicago and a colleague of Sen. She expands his inventory of capabilities to include life, bodily health, bodily integrity, senses, imagination, thought, emotions, practical reason, affiliation, play, and control over one's environment as necessaries for achieving one's well-being [8]. With a focus on women's issues, she addresses gender disparity throughout the world and applies capability theory to explain the "compelling evidence of discrimination against females in many nations of the world" ([8], p. 304). Although Nussbaum's emphasis is on the denial of opportunities for women, the same theoretical application can be applied to the "compelling evidence" denying condemned prisoners any capacity for controlling their futures as well. This quite naturally raises the salient question: what are members of an incarcerated cohort actually able to do with respect to achieving those goals? Here the discussion diverges into two primary arguments, one existential, the other moral.

Following the existential path, S. Charusheela, a professor at the University of Washington, Bothell, responds to Nussbaum's arguments by insisting that the women she studied and their culturally imposed illiteracy, rather than supporting her argument, serve as a rebuke of her and Sen's philosophical definition of human dignity. Charusheela insists that the women were on equal economic terms with their male counterparts in those cultures, primarily because they occupied a valued place in an agrarian society and were respected for their contributions [9]. Yes, but what if only one of those women wanted to transcend those cultural and geographical boundaries? If her focus did not have an economic basis but an artistic or academic one, what then? Her illiteracy would certainly prevent her 
from achieving what she wanted, a clear violation of Sen's capabilities approach and a validation of a more inclusive definition of human dignity.

As Sen has it

The basic idea here is to pay attention to the actual "capabilities" that people end up having. The capabilities depend both on our physical and mental characteristics as well as on social opportunities and influences (and can thus serve as the basis not only of assessment of personal advantage but also of efficiency and equity of social policies) ([10], p. 126).

Extending Charusheela's critique to prison and death row, if some condemned prisoners' confinement on death row resulted in reduced goals that approximated those that could be achieved via their daily routine prior to conviction, their human dignity would be preserved - at least until the government put them to death. The problem with this approach lies in the capacity for adaptation based exclusively on a subjective interpretation:

People can internalize the harshness of their circumstances so that they do not desire what they can never expect to achieve. This is the phenomenon of "adaptive preferences", in which people who are objectively very sick may, for example, still declare, and believe, that their health is fine. Therefore, evaluation that focuses only on subjective mental metrics is insufficient without considering whether that matches with what a neutral observer would perceive as their objective circumstances (italics in original) [11].

And what of those men and women whose existence on death row prohibits their capability to achieve their goals above mere survival? What if those same men and women want more than the simple economic stability of food, clothing, and shelter? This is where theory becomes divorced from reality.

When applied to prisoners, especially those on death row or serving life without parole, the philosophical construct that focuses on a group's existential capabilities to preserve human dignity is incomplete. In order to protect the welfare of the majority, society has designed and erected prisons precisely to limit or prevent prisoners from enjoying the same capabilities Nussbaum and Sen articulate. More important, as Robert Johnson has extensively documented, many prisoners conform to the theory of adaptive preferences by constricting their goals in order to adjust to their environment and preserve their lives as long as possible. After decades, some prisoners, in a troubling iteration of Stockholm syndrome, come to view their lives and routines as "normal", with all the personal necessities provided, and do their best to make those meager existences the least stressful as possible. Any deviations can bring disproportionate consequences, up to and including an expedited execution.

Actions that reflect autonomy, or that can be construed as manifestations of adult independence, may be viewed by staff as acts of disobedience and may increase the risks inmates face in encounters with staff. Certainly the intentional killing of any human being by anyone constitutes a violation of that individual's dignity. Compounding the problem is society's imprimatur given the executions ([12], p. 69).

According to a strict capabilities interpretation, simply being able to have access to books and outdoor exercise would preserve the prisoner's human dignity by satisfying the philosophical requirements of providing what the prisoner needs to achieve his or her goals: eating three meals a day, watching television, reading a book, and having the occasional visit.

Reflected in this Spartan backdrop is society's intent to deny any capability for achieving a worthwhile life, a practice to which Sen would vigorously object, insisting that "we have to see individual freedom as a social commitment" ([6], p. xii). Prisoners, irrespective of contrary assertions, do not cease being human, although more than a few of Johnson's correctional interviewees characterized them as a subspecies unworthy of consideration [12]. They should therefore be accorded treatment that preserves their human dignity—which excludes execution-although they 
cannot, in Sen's model, exert any but the most primitive control over their physical environment and affiliations.

A wider, more comprehensive approach, both legal and philosophical, better and more rationally addresses the pernicious result of prolonged confinement and sentence of death. As Nussbaum forcefully points out, "customs and political arrangements are important causes of...misery and death" ([8], p. 304). Robert Johnson's argument for a universal, non-economic approach to human dignity correctly recognizes that condoning — or even simply accepting — a practice because tradition has endorsed it fails, in Nussbaum's terms, by "withholding critical judgment where real evil and oppression are surely present" ([8], p. 305). As Johnson has cogently argues, individuals' fundamental humanity requires that their personal dignity be preserved even when their capabilities have been severely compromised, which means not having their lives taken by the au courant style of execution.

The death penalty, Johnson reminds us, is a violation of human dignity because it intentionally sanctions the killing of another human being by the state. Moreover, it deprives the prisoner of those economic opportunities Sen insists must characterize a moral society. Johnson grimly describes the result when those opportunities are absent: "The condemned prisoner's ordeal is usually a lonely one and must be met largely through his own resources" ([12], p. 4).

Both Sen and Nussbaum are highly critical of any social policy that reduces or eliminates an individual's ability to achieve self-defined goals. This criticism would include capital punishment. If they are correct, then the radical reduction of goals and the ability to achieve them in response to a death sentence must result in a loss of human dignity, even if the prisoner, like the illiterate women cited by Nussbaum, is still able to achieve other, more restricted aspirations. This accords with Johnson's position that the denial of one's basic humanity is the key, which naturally leads to the denial of human dignity, irrespective of the prisoner's personal goals.

Both Amartya Sen and Robert Johnson recognize the philosophical and moral obligations that underlie our commonality: to treat all people with dignity. But, whereas Sen's approach emphasizes personal subjective capability, Johnson's is more inclusive and must extend to the prison and especially to death row with respect to the treatment of the men and women confined there, because personal preferences are not always reliable indicators of life quality and may be distorted by oppression and deprivation. As Nussbaum correctly points out, "[s]tated satisfactions and preferences...may be deformed by intimidation, lack of information, and habit" ([8], p. 305).

Long-term confinement and sentence of death frequently produce the identical reaction in prisoners, as Robert Johnson's books and articles verify. The result is that people identify their capabilities exogenously rather than endogenously and "frequently adjust their expectations to the low level of well-being they think they can actually attain" ([13], p. 123). How, then, can a sentence of death be anything but an objective denial of human dignity? Accordingly, the discussion must be framed in objective, rather than subjective, terms.

If all people are viewed as individuals, not part of a specific group (or, in the case of prisoners, a subhuman species), defining human dignity exclusively in terms the capability of achieving one's goals relies entirely too much on personal interpretations that are subject to oppressive influences. A broader approach, articulated by Robert Johnson, is the superior one that should be applied across the board to all human beings, irrespective of their often truncated personal goals.

Author Contributions: Susan Nagelsen conceived the idea for the paper after interactions with some of her students and colleagues. She wrote the final paper. Charles Huckelbury helped research the sources, verify citations, and write several preliminary drafts.

Conflicts of Interest: The authors declare no conflict of interest.

\section{References}

1. Henry, Leslie. "The Jurisprudence of Dignity." University of Pennsylvania Law Review 160 (2011): 169-233.

2. ABC News. "Eyewitness Accounts of McVeigh's Execution." 2001. Available online: http://abcnews.go. com/US/story?id=90542\&page=1 (accessed on 12 April 2016). 
3. Duhaime's Law Dictionary. Available online: www.duhaime.org (accessed on 7 February 2016).

4. Schmeiser, Susan. "Chapter 3-Waiving from Death Row." In Who Deserves to Die: Constructing the Executable Subject. Edited by Austin Sarat and Karl Shoemaker. Amerst: University of Massachusetts Press, 2011.

5. Johnson, Robert. "Reflections on the Death Penalty: Human Rights, Human Dignity, and Dehumanization in the Death House." Seattle Journal for Social Justice 13 (2015): 582-98.

6. Sen, Amartya. Development as Freedom. Oxford: Oxford University Press, 1999.

7. Robeyns, Ingrid. "The Capability Approach." In The Stanford Encyclopedia of Philosophy. Edited by Edward N. Zalta. Stanford: Center for the Study of Language and Information, 2011. Available online: http:/ / plato.stanford.edu/archives/sum2011/entries/capability-approach/ (accessed on 8 April 2016).

8. Nussbaum, Martha. "Women and Cultural Universals." In Feminist Theory: A Philosophical Anthology. Edited by Ann Cudd and Robin Andreasen. Oxford: Wiley-Blackwell, 2005, pp. 302-24.

9. Charusheela, S. "Social analysis and the capabilities approach: A limit to Martha Nussbaum's universalist ethics." Cambridge Journal of Economics 33 (2009): 1135-52. [CrossRef]

10. Irudayam, Charles. Towards an Ethical Framework for Poverty Reduction. Delhi: Tercentenary Publication, 2010.

11. Internet Encyclopedia of Philosophy. "Sen's Capabilities Approach." 2016. Available online: http:/ /www. iep.utm.edu/sen-cap/ (accessed on 12 February 2016).

12. Johnson, Robert. Condemned to Die. Prospect Heights: Waveland Press, 1989.

13. Sen, Amartya. "Gender and Cooperative Conflicts." In Persistent Inequalities: Women and World Development. Edited by Irene Tinker. New York: Oxford University Press, 1990.

(C) 2016 by the authors; licensee MDPI, Basel, Switzerland. This article is an open access article distributed under the terms and conditions of the Creative Commons Attribution (CC-BY) license (http://creativecommons.org/licenses/by/4.0/). 